\title{
Addition of cellulolytic bacteria in complete feed block based on agro-industrial by- products for Kacang goats
}

\author{
B. Santoso", T.W. Widayati, B.T. Hariadi \& M.N. Lekitoo \\ Department of Animal Science, Faculty of Animal Science, University of Papua, Manokwari, West Papua 98314 \\ Indonesia
}

(Received 29 August 2020; Accepted 30 March 2021; Published 9 June 2021)

\begin{abstract}
Copyright resides with the authors in terms of the Creative Commons Attribution 4.0 South African Licence.
See: http://creativecommons.org/licenses/by/4.0/za

Condition of use: The user may copy, distribute, transmit and adapt the work, but must recognise the authors and the South African Journal of Animal Science.
\end{abstract}

\begin{abstract}
The research aimed at assessing the effects on nutrient digestion and ruminal fermentation by goats of a complete feed block (CFB) that incorporated agro-industrial by-products that were high in fibre and cellulolytic bacteria. Three Kacang goats, a native Indonesian breed, were used in a $3 \times 3$ Latin square experimental design with i) CFB without microbes (control), ii) CFB containing $1 \%$ Pseudomonas aeruginosa and $1 \%$ Acinetobacter baumannii, and iii) CFB containing $2 \%$. aeruginosa and $2 \% A$. baumannii. Microbes in the CFBs consisted of lactic acid bacteria, yeast and cellulolytic bacteria that ranged from $10^{6}$ to $10^{8} \mathrm{cfu} / \mathrm{g}$. The goats were fed each day at $08 \mathrm{~h} 00$ and $16 \mathrm{~h} 00$. The inclusion of $P$. aeruginosa and $A$. baumannii at $2 \%$ level reduced both neutral detergent fibre (NDF) and acid detergent fibre compared with other treatments. Goats fed on CFB with microbes had higher $(P<0.01)$ digestibility of organic matter $(\mathrm{OM})$ and NDF compared with control. The addition of $P$. aeruginosa and $A$. baumannii at $2 \%$ level increased $(P<0.05)$ ruminal ammonia nitrogen $\left(\mathrm{N}-\mathrm{NH}_{3}\right)$, acetate, and total VFA. However, goats fed on CFB with microbes had lower $(P<0.05)$ urinary $\mathrm{N}$ excretion, which improved $(P<0.05) \mathrm{N}$ retention compared with the control. It was concluded that a combination of lactic acid bacteria, yeast and cellulolytic bacteria in the CFB could modify fermentation in the rumen and increase the use of nitrogen in goats.
\end{abstract}

Keywords: ammonia, cellulase, intake, rumen

\#Corresponding author: b.santoso@unipa.ac.id

\section{Introduction}

The cost of feed in animal husbandry management is $60-70 \%$ of total production costs. Therefore it is necessary to attend to the quantity and quality of feed. Forages are often combined with concentrate and feed additives to increase livestock production and productivity. Rice straw and palm fronds are agricultural and plantation wastes that are abundantly available in Manokwari regency. Santoso and Hariadi (2009) and Santoso et al. (2017) reported that crude protein (CP) and neutral detergent fibre (NDF) contents in rice straw and oil palm fronds were $6.8 \%$ and $4.4 \%$, and $71.1 \%$ and $79.2 \%$, respectively, and thus require nutritional augmentation in order to be used effectively as feedstuffs for ruminant livestock.

Total feed block (CFB) is a product that is made up of forage, concentrate, and nutrients in chosen proportions that meet animals' nutritional requirements. Feeding CFB stabilizes the fermentation of rumen, lessens the loss of fermentation, and guarantees better utilization of ammonia (Prasad et al., 2001). The technology also boosts milk production, causes fewer environmental pollutants, raises farmers' income, has lower labour requirements, requires less time to feed, and lowers the cost of transporting straw (Karangiya et al., 2016).

Microbes digest feed in the rumen and the types and populations of these microbes affect nutrient digestibility. Lactic acid bacteria (LAB) are widely used as probiotics in cattle to enhance digestibility, microbial balance, and health of animals (Uyeno et al., 2015). Organisms such as Lactobacillus, Streptococcus and Enterococcus are among the commonly used probiotics for ruminants (Seo et al., 2010). Ridwan et al. (2018) reported that $L$. plantarum strain 32 isolated from cow rumen had higher in vitro dry matter and organic matter digestibilities and overall production of gas in comparison with the control. Oyeleke and Okusanmi (2008) stated that $P$. aeruginosa inhabited the rumen of cows, sheep, and goats and 
could hydrolyse cellulose. Chang et al. (2015) concluded that Acinetobacter sp. in the rumen of Korean native cattle belonged to cellulolytic bacteria. Moreover, Surabhi et al. (2018) noted that $A$. baumannii is a gut bacterium that has the ability to degrade cellulose. Santoso et al. (2016) added Lactobacillus plantarum, Saccharomyces cerevisiae, A. baumannii and $P$. aeruginosa to the concentrate and observed enhanced fermentation and in vitro nutrient digestibility. Moreover, Santoso et al. (2018) concluded that the additions of $\mathrm{LAB}$, yeast, and cellulolytic bacteria to CFB altered in vitro patterns of ruminal fermentation by increasing the concentrations of ammonia nitrogen $\left(\mathrm{NH}_{3}-\mathrm{N}\right)$ and total VFAs and reducing the production of methane. This study was conducted to evaluate the digestibility of nutrients, characteristics of rumen fermentation and the utilization of nitrogen in Kacang goats fed agro-industrial by-product-based CFBs treated with cellulolytic bacteria.

\section{Materials and Methods}

This study was performed according to the standard procedures of rearing and treating farm animals stated in the Law of the Republic of Indonesia, number 18, 2009.

The study collected rice straw and palm oil fronds from the paddy fields and palm oil plantation regions in Prafi district in Manokwari regency in Indonesia at longitude $133^{\circ} 48^{\prime} \mathrm{E}$ and a latitude of $00^{\circ} 53^{\prime} \mathrm{S}$ with an average altitude of 52 metres above sea level. To formulate the CFB, the rice straw and palm oil fronds were sun dried and chopped into lengths of one to two centimetres. Both types of waste were oven dried at $60{ }^{\circ} \mathrm{C}$ for $48 \mathrm{hrs}$. Then they were ground and passed through a $1-\mathrm{mm}$ sieve using a Wiley mill. The L. plantarum was isolated from Pennisetum purpureophoides (Santoso et al., 2017; Santoso et al. 2018). It was cultivated in MRS broth at $30{ }^{\circ} \mathrm{C}$ for 48 hours. In the meantime, S. cerevisiae was cultivated from malt extract broth at $30{ }^{\circ} \mathrm{C}$ for 48 hours (Santoso et al., 2017; Santoso et al., 2018). Cellulolytic bacteria $P$. aeruginosa and $A$. baumannii were isolated from the rice straw and the palm oil seed wastes, and cultured with carboxymethyl cellulose. The CFB ingredients were mixed manually and then sprayed on top with $L$. plantarum, Saccharomyces cerevisiae, $P$. aeruginosa, and A. baumannii at $>1.05 \times 10^{5}, 9.45 \times 10^{8}, 9.6 \times$ $10^{8}$, and $>1.01 \times 10^{8} \mathrm{cfu} / \mathrm{ml}$, respectively. All CFBs were formulated to be isonitrogenous $(14 \% \mathrm{CP}$, DM basis). Around $300 \mathrm{~g}$ of blended material was placed in a hydraulic press to create a block measuring $15 \times$ $10 \times 8 \mathrm{~cm}$. The three dietary treatments (Table 1) consisted of A) CFB without microbes, B) CFB with $1 \% P$. aeruginosa and $1 \% A$. baumannii, and C) CFB with $2 \% P$. aeruginosa and $2 \% A$. baumannii.

Table 1 Ingredients contained in complete feed blocks for Kacang goats made using agro-industrial byproducts

\begin{tabular}{lccc}
\hline \multirow{2}{*}{ Ingredients, \% } & \multicolumn{3}{c}{ Complete feed blocks } \\
\cline { 2 - 4 } & $\mathrm{A}$ & $\mathrm{B}$ & $\mathrm{C}$ \\
\hline Rice straw & 12 & 12 & 12 \\
Palm oil frond & 25 & 25 & 25 \\
Cassava waste & 23 & 23 & 23 \\
Tofu waste & 17 & 17 & 17 \\
Molasses & 20 & 20 & 20 \\
Urea & 1.5 & 1.5 & 1.5 \\
Premix & 1.5 & 1.5 & 1.5 \\
Microbes & & & 1.5 \\
Lactobacillus plantarum & 0 & 1.5 & 1.5 \\
Saccharomyces cerevisiae & 0 & 1.5 & 2 \\
Pseudomonas aeruginosa & 0 & 1 & 2 \\
Acinetobacter baumannii & 0 & 1 & \\
\hline A:complete
\end{tabular}

A: complete feed block without microbes; B: complete feed block containing $1 \% P$. aeruginosa and $1 \%$ A. baumannii; C: complete feed block containing $2 \% P$. aeruginosa and $2 \% A$. baumannii

${ }^{1}$ Composition (per kg): $70 \mathrm{~g}$ calcium, $189 \mathrm{~g}$ phosphorus, $12 \mathrm{~g}$ magnesium, $300.000 \mathrm{IU}$ vitamin A, 50.000 IU vitamin D3, $100 \mathrm{mg}$ vitamin E, $100 \mathrm{mg}$ vitamin K, $20 \mathrm{~g}$ trace elements ( $\mathrm{Zn}, \mathrm{Mn}, \mathrm{Fe}, \mathrm{Cu}, \mathrm{I}, \mathrm{Co}, \mathrm{Mo}, \mathrm{Se})$ 
Three male Kacang goats with a preliminary bodyweight (BW) of $19.8 \pm 2.72 \mathrm{~kg}$ were used in a $3 \times 3$ Latin square design. Prior to the start of the experiment, the goats were dewormed with $10 \mathrm{mg} / \mathrm{kg} \mathrm{BW}$ Kalbazen (PT Kalbe Farma, Jakarta, Indonesia). The goats were kept in three separate metabolism cages, which enabled the collection of urine and faeces separately. The goats were fed the CFBs twice daily at $08 \mathrm{~h} 00$ and $16 \mathrm{~h} 00$ at a dry matter (DM) intake of $66 \mathrm{~g} \mathrm{DM} / \mathrm{kg} \mathrm{BW}^{0.75} /$ day (Kearl, 1982). Salt licks and fresh water were accessible ad libitum. Each phase lasted for two weeks, that is, eight days to acclimatize to the diet, five days to collect urine and faeces, and one day to sample rumen liquor. The goats were weighed at the start and the end of each phase.

At days 9 through 13 of each phase, each goat's overall faeces and urine excretions were collected and weighed. Individual feed refusals, if any, were collected and weighed every day, and samples were taken for analyses. Sub-samples of faeces were kept at $-15{ }^{\circ} \mathrm{C}$ for further analysis. Urine was collected in buckets containing $50 \mathrm{ml}$ of $100 \mathrm{~mL} / \mathrm{L}(\mathrm{v} / \mathrm{v})$ sulphuric acid to lower the $\mathrm{pH}$ and get it under 3.0 and to avert bacterial obliteration of $\mathrm{N}$. Around $50 \mathrm{~mL} / \mathrm{L}$ of the urine was sub-sampled and maintained at $-15{ }^{\circ} \mathrm{C}$ until $\mathrm{N}$ was assessed.

On the final day of each period, around $20 \mathrm{ml}$ of rumen fluid was collected via the oesophagus with a flexible stomach tube attached to a vacuum pump prior to the goats being fed and 1,2 and 4 hours after they had been fed in the morning. Afterwards, this rumen fluid was strained through four layers of cheesecloth. Immediately after it was sampled, the $\mathrm{pH}$ was recorded with a digital $\mathrm{pH}$ meter (HANNA, Hi9321, Ronchidi Villafranca, Italy). To evaluate $\mathrm{NH}_{3}-\mathrm{N}, 5 \mathrm{~mL}$ sub-samples of filtrate were added to $5 \mathrm{ml}$ of $20 \mathrm{~mL} / \mathrm{L}(\mathrm{w} / \mathrm{v}) \mathrm{NaCl}$. Samples to determine volatile fatty acids (VFA) were stabilized with a $46 \mathrm{mM}$ mercuric chloride $\left(\mathrm{HgCl}_{2}\right)$ solution $\left(200 \mu \mathrm{L} / 1.8 \mathrm{ml}\right.$ rumen fluid) and stored at $-15^{\circ} \mathrm{C}$ for analysis.

The faeces and feed samples were dried in an oven at $60^{\circ} \mathrm{C}$ to $70^{\circ} \mathrm{C}$ until constant weight, ground to pass a 1-mm sieve and then utilized in a chemical analysis. Feeds and faeces were dried in an oven at 105 ${ }^{\circ} \mathrm{C}$ for 24 hours to determine DM content. Organic material (OM) was obtained after ashing samples at 550 ${ }^{\circ} \mathrm{C}$ for four hours and $\mathrm{N}$ was determined with the Kjeldahl technique (AOAC, 2012). Neutral detergent fibre and acid detergent fibre (ADF) were analysed as prescribed by Van Soest et al. (1991). Neutral detergent fibre and ADF were expressed inclusive of the remaining ash. Nutrient digestibility was calculated as:

$$
\text { Digestibility }=\frac{\text { nutrient consumed }- \text { nutient in faeces }}{\text { nutrient consumed }} \times 100
$$

Data were analysed using a $3 \times 3$ Latin square design with three treatments and three replicates of treatments, following the GLM procedure of SAS version 9.1 (SAS Institute, Cary, North Carolina, USA). The mathematical model was:

$$
Y_{i j k}=\mu+H_{i}+R_{j}+P_{k}+e_{i j k}
$$

where: $Y_{i j k}=$ a dependent variable for the ith animal, jth treatment, and kth trial period;

$\mu=$ general mean,

$H_{i}=$ effect of the ith animal,

$R_{j}=$ effect of jth treatment,

$P_{k}=$ effect of the kth trial period, and

$e_{i j k}=$ residual effect used as error

Means were compared with Duncan's multiple range tests at probability levels of $5 \%$ and $1 \%$.

\section{Results and Discussion}

All CFBs were light brown, compact in shape, and exuded a distinctive molasses aroma. After storage for three months, their colour had not changed, and no yeast had grown. These findings were consistent with observations by Santoso et al. (2017).

The chemical compositions of the CFBs in the experiment are summarized in Table 2. The average DM and OM contents in all CFBs were $77.7 \%$ and $91.1 \%$, respectively, which were comparable with a palm oil frond-based CFB (Santoso et al., 2017).

The mean CP in all the CFBs equalled $14 \%$, which was above the threshold value of $7 \%$ required to support rumen microbial activity. Below this threshold, digestibility declines because microbial activity in the rumen has been found to be depressed due to the lack of N (Minson \& Milford, 1966). The similar amount of $\mathrm{CP}$ in all the CFBs verifies the intent that the feeds were iso-nitrogenous. 
Table 2 Chemical composition of complete feed blocks for Kacang goats made using agro-industrial byproducts

\begin{tabular}{lccc}
\hline \multirow{2}{*}{ Variables } & \multicolumn{3}{c}{ Complete feed blocks } \\
\cline { 2 - 4 } & A & B & C \\
\hline Dry matter (\%) & 78.6 & 77.7 & 76.9 \\
Organic matter (\%) & 90.5 & 91.6 & 91.2 \\
Crude protein (\%) & 14.7 & 13.3 & 14.0 \\
NDF (\%) & 55.2 & 46.1 & 42.5 \\
ADF (\%) & 36.9 & 33.1 & 27.9 \\
Hemicellulose (\%) & 13.3 & 13.0 & 14.6 \\
Total microbes (cfu/g) & - & $9.92 \times 10^{8}$ & $>1.42 \times 10^{9}$
\end{tabular}

A: complete feed block without microbes; B: complete feed block containing $1 \% P$. aeruginosa and $1 \% A$. baumannii; C: complete feed block containing $2 \% P$. aeruginosa and $2 \%$ A. baumannii. NDF: neutral detergent fibre; ADF: acid detergent fibre

The NDF and ADF contents of blocks $C$ and $B$ were lower than block $A$, which to some extent might have been because of cellulolytic bacteria in the CFB. Previously, Van Soest (1994) had commented that microbial enzymes could lower the levels of NDF.

The $\mathrm{pH}$ value, concentrations of $\mathrm{NH}_{3}-\mathrm{N}$, and individual and total VFAs are presented in Table 3 . Propionate and butyrate concentrations and acetate to propionate ratio in the rumen were unchanged $(P$ $>0.05$ ) by treatment.

Table 3 Rumen fermentation characteristics in Kacang goats fed a complete feed block

\begin{tabular}{|c|c|c|c|c|c|}
\hline \multirow{2}{*}{ Variables } & \multicolumn{3}{|c|}{ Complete feed blocks } & \multirow{2}{*}{ SE } & \multirow{2}{*}{$P$-value } \\
\hline & A & $B$ & C & & \\
\hline $\mathrm{pH}$ & 6.75 & 7.00 & 6.94 & 0.13 & 0.49 \\
\hline $\mathrm{N}-\mathrm{NH}_{3}(\mathrm{mg} / 100 \mathrm{~mL})$ & $65.9^{b}$ & $70.5^{\mathrm{ab}}$ & $85.5^{\mathrm{a}}$ & 1.06 & 0.01 \\
\hline Acetate (mM) & $62.2^{b}$ & $65.9^{\mathrm{ab}}$ & $71.3^{\mathrm{a}}$ & 0.49 & 0.01 \\
\hline Propionate (mM) & 17.5 & 18.6 & 18.8 & 0.46 & 0.30 \\
\hline Butyrate (mM) & 7.2 & 8.6 & 9.3 & 0.54 & 0.21 \\
\hline Total VFA (mM) & $86.9^{b}$ & $93.4^{\mathrm{ab}}$ & $99.4^{\mathrm{a}}$ & 0.53 & 0.01 \\
\hline Acetate : propionate & 3.5 & 3.6 & 3.8 & 0.08 & 0.21 \\
\hline
\end{tabular}

A: complete feed block without microbes; B: complete feed block containing $1 \% P$. aeruginosa and $1 \%$ A. baumannii; C: complete feed block containing $2 \% P$. aeruginosa and $2 \% A$. baumannii; $\mathrm{N}-\mathrm{NH}_{3}$ : ammonia nitrogen; VFA: volatile fatty acids

${ }_{a, b}$ Within a row means were a common superscript did not differ with probability $(P<0.01)$

The rumen $\mathrm{pH}$ values of goats fed on CFB were not different $(P>0.05)$. Aschenbach et al. (2011) stated that rumen $\mathrm{pH}$ was dependent on saliva production, the absorption and generation of short-chain fatty acids, the type and amount of feed intake, and exchange of phosphates and bicarbonates via the ruminal epithelium. $\mathrm{pH}$ values in the rumen are relatively changeable, and the usual values range from 5.5 to 7.0 (Krause \& Oetzel, 2006). Nonetheless, pH values in all treatments fluctuated from 6.75 to 7.00 and stayed within the range believed to be ideal for microbial digestion action. Zhang et al. (2017) determined that cellulose degradation by rumen microorganisms occurs at $\mathrm{pH}$ values between 5.5 and 7.5 , with the highest degradation being attained at 6.5. Russell and Wilson (1996) demonstrated that rumen cellulolytic bacteria are exceptionally sensitive to acidity and a ruminal $\mathrm{pH}$ less than 6.0 to 6.2 was disadvantageous to bacterial growth. The diurnal pattern of ruminal pH in goats fed on CFB is presented in Figure 1. 


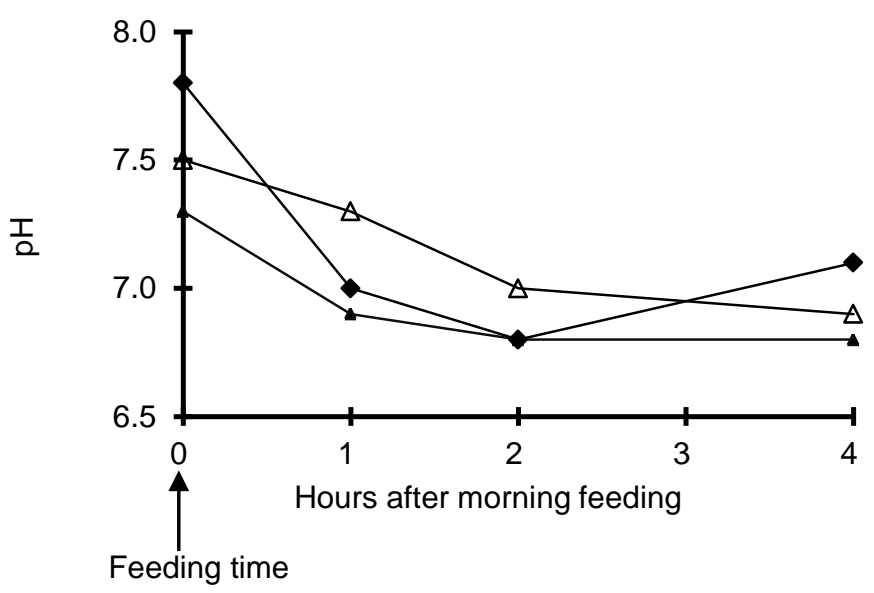

Figure 1 Diurnal pattern of ruminal $\mathrm{pH}$ in goats fed ( $\downarrow$ CFB without microbes; $(\Delta)$ CFB containing $1 \% P$. aeruginosa and $1 \% A$. baumannii; ( $\mathbf{\Lambda}$ ) CFB containing $2 \% P$. aeruginosa and $2 \% A$. baumannii

Protein and additional nitrogenous materials are broken down into peptides and ammonia in the rumen (Bach et al., 1988). The microbes utilize the ammonia to synthesize protein. Goats that were fed block $\mathrm{C}$ had the highest $(P<0.01) \mathrm{NH}_{3}-\mathrm{N}$ concentration compared with other diets. The trend in increase in $\mathrm{NH}_{3}-\mathrm{N}$ concentration in goats fed on blocks $B$ and $C$ was supported by an increase in CP digestibility (Table 4).

Table 4 Apparent nutrient digestibility (\%) in Kacang goats fed a complete feed block

\begin{tabular}{|c|c|c|c|c|c|}
\hline \multirow{2}{*}{ Variables } & \multicolumn{3}{|c|}{ Complete feed blocks } & \multirow{2}{*}{ SE } & \multirow{2}{*}{$P$-value } \\
\hline & A & $B$ & $\mathrm{C}$ & & \\
\hline Dry matter & 55.7 & 57.7 & 58.7 & 1.77 & 0.59 \\
\hline Organic matter & $58.2^{\mathrm{b}}$ & $60.2^{\mathrm{a}}$ & $62.0^{\mathrm{a}}$ & 0.13 & 0.01 \\
\hline Crude protein & 52.6 & 54.3 & 57.3 & 0.75 & 0.09 \\
\hline NDF & $42.2^{\mathrm{c}}$ & $45.9^{\mathrm{b}}$ & $48.6^{\mathrm{a}}$ & 0.17 & 0.01 \\
\hline
\end{tabular}

A: complete feed block without microbes; B: complete feed block containing $1 \% P$. aeruginosa and $1 \%$ A. baumannii; C: complete feed block containing $2 \% P$. aeruginosa and $2 \% A$. baumannii. NDF: neutral detergent fibre

${ }_{\mathrm{a}, \mathrm{b}}$ Within a row means were a common superscript did not differ with probability $P<0.01$

The $\mathrm{NH}_{3}-\mathrm{N}$ concentrations in the rumen varied from 65.0 to $85.5 \mathrm{mg} / 100 \mathrm{ml}$. Diurnal patterns of ruminal $\mathrm{NH}_{3}-\mathrm{N}$ concentration in goats fed on CFB are illustrated in Figure 2. McDonald et al. (2010) stated that the required optimum concentrations of rumen $\mathrm{NH}_{3}-\mathrm{N}$ to increase microbial protein synthesis was from 8.5 to $30 \mathrm{mg} / \mathrm{dl}$ and more. Abdulrazak et al. (1997) stated that between $5 \mathrm{mg} / \mathrm{dl}$ and $8 \mathrm{mg} / 100 \mathrm{~mL}$ of rumen liquor was enough to digest fibre. Consequently, in the current research, the ammonia $\mathrm{N}$ in every treatment of CFB was enough to guarantee optimal microbial development and digestion of fibre. 




Figure 2 Diurnal patterns of ruminal $\mathrm{N}-\mathrm{NH}_{3}$ concentration in goats fed $(\bullet)$ CFB without microbe; $(\Delta)$ CFB containing $1 \% P$. aeruginosa and $1 \% A$. baumannii; ( $\Delta$ ) CFB containing $2 \% P$. aeruginosa and $2 \% A$. baumannii

Carbohydrates are fermented by bacteria in the rumen and are transformed into volatile fatty acids (VFAs), which provide the main energy for ruminants. The ratios of butyrate, propionate, and acetate that are generated in the rumen are influenced by the type of forage and the composition and amount of rumen bacteria (Wang et al., 2020). Block $C$ had higher $(P<0.01)$ productions of acetate and total VFA than blocks $B$ and $A$. The higher VFA concentration in goats fed on blocks $B$ and $C$ could be because of higher OM digestibility (Table 4). The capability to decompose cellulose is dependent on the kind of forage and crop maturity, along with the types of cellulolytic bacteria (Fondevila \& Dehorty, 1996). Dijkstra (1994) determined that the fermentation of structural carbohydrates generated a large quantity of acetic acid and a small quantity of propionic acid compared with starch. Block $C$ produced the highest $(P<0.01)$ concentration of acetate, followed by blocks A and B. Wang et al. (2020) observed that fibre-degrading bacteria generated a large quantity of acetate in goat rumen. Acetate is associated with fermentation of the cell wall, and the increase in the level of acetate is typically related to the diminishing quality of the forage (Van Soest, 1994). In the present study, peak ruminal VFA concentration occurred at 1 hour after feeding in all treatments (Figure 3).

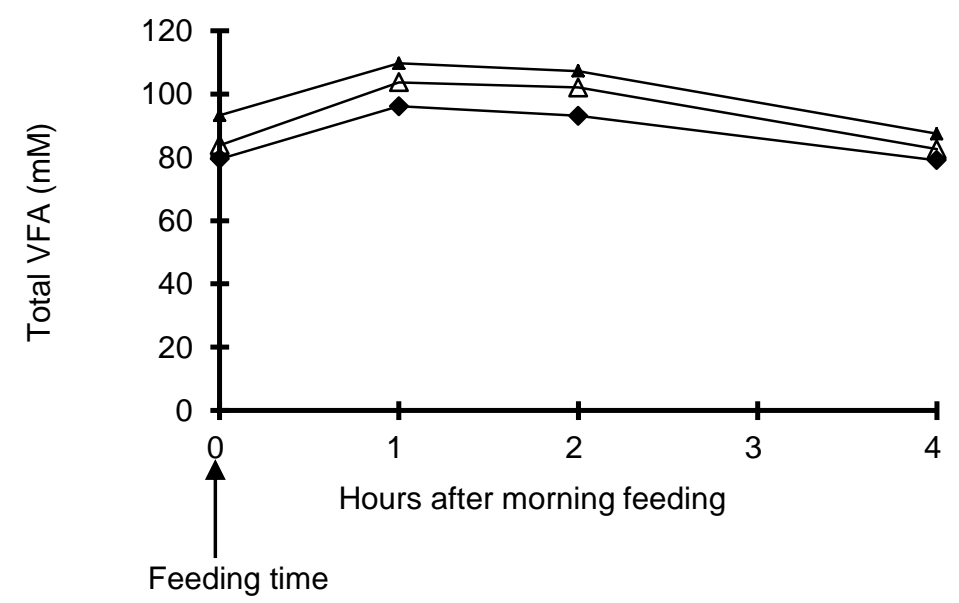

Figure 3 Diurnal pattern of ruminal total VFA concentration in goats fed $(\diamond)$ CFB without microbes; $(\Delta)$ CFB with $1 \%$ Pseudomonas aeruginosa and $1 \%$ Acinetobacter baumannii; $(\mathbf{\Lambda})$ CFB with $2 \%$ P. aeruginosa and $2 \%$ A. baumannii 
Blocks $\mathrm{B}$ and $\mathrm{C}$ produced greater OM digestibility $(P<0.05)$ and NDF digestibility $(P<0.01)$ compared with block $A$ (Table 4). The greater digestibility of NDF may be because of the addition of cellulolytic bacteria to the feed block. This result was consistent with the finding of Santoso et al. (2017) in which block B produced the greatest in vitro digestibility of DM, OM and NDF compared with the other feeds. Zain et al. (2015) reported that the addition of microbes to feed to act as probiotics stimulated rumen microbes and improved feed digestibility in ruminants.

There was no significant difference in $\mathrm{N}$ intake, digested $\mathrm{N}$, faecal $\mathrm{N}$ and retained $\mathrm{N}$ among rations (Table 5). Urinary $\mathrm{N}$ excretion was at the lowest level $(P<0.05)$ in block $\mathrm{C}$, intermediate in block $\mathrm{B}$, and highest in block $\mathrm{A}$. Urinary $\mathrm{N}$ excretion as a percentage of $\mathrm{N}$ intake in blocks $\mathrm{C}$ and $\mathrm{B}$ was lower $(P<0.05)$ than the control. Goats fed blocks $\mathrm{B}$ and $\mathrm{C}$ had higher $(P<0.05)$ retained $\mathrm{N}$ expressed as a proportion of digested $\mathrm{N}$ compared with control. The lower $\mathrm{N}$ loss in urine was indicative of lower absorption of $\mathrm{N}$ and resulted in a higher retained $\mathrm{N}$ as a proportion of digested N. Santoso et al. (2007) concluded that lower $\mathrm{N}$ loss in urine reflected lower absorption of $\mathrm{N}$ and resulted in a higher ratio of retained $\mathrm{N}$ to $\mathrm{N}$ digested. In the present study, urine $\mathrm{N}$ excretion as a percentage of $\mathrm{N}$ intake fluctuated between $25 \%$ and $30.7 \%$, which was lower than the findings reported by Zhu et al. (2020), which ranged from $37.8 \%$ to $43.2 \%$. The amount of $\mathrm{N}$ excreted indicates protein consumption and the effectiveness of $\mathrm{N}$ deposition. Consequently, the lower total of $\mathrm{N}$ excretion (percentage of $\mathrm{N}$ intake) in goats given blocks $\mathrm{C}$ and $\mathrm{B}$ showed that these diets could reduce environmental $\mathrm{N}$ pollution. Urinary $\mathrm{N}$ is changed to ammonia quickly and is volatilized into the air, whereas faecal $\mathrm{N}$ is changed to ammonia at a slower rate (Bussink \& Oenema, 1998).

Table 5 Nitrogen balance and nitrogen partition in Kacang goats fed complete feed blocks

\begin{tabular}{|c|c|c|c|c|c|}
\hline \multirow{2}{*}{ Variables } & \multicolumn{3}{|c|}{ Complete feed blocks } & \multirow{2}{*}{ SE } & \multirow{2}{*}{$P$-value } \\
\hline & A & B & C & & \\
\hline \multicolumn{6}{|l|}{ Nitrogen $(\mathrm{N})$ balance (g/day) } \\
\hline $\mathrm{N}$ intake & 12.7 & 11.9 & 12.9 & 0.15 & 0.09 \\
\hline Faecal N & 6.3 & 5.7 & 5.6 & 0.21 & 0.21 \\
\hline Digested N & 6.4 & 6.2 & 6.4 & 0.34 & 0.84 \\
\hline Urinary $\mathrm{N}$ & $3.9^{\mathrm{a}}$ & $3.2^{\mathrm{b}}$ & $3.0^{\mathrm{b}}$ & 0.11 & 0.05 \\
\hline Retained N & 2.5 & 3.0 & 3.4 & 0.23 & 0.19 \\
\hline \multicolumn{6}{|l|}{ Nitrogen partition } \\
\hline Faecal $N / N$ intake & 49.7 & 48.1 & 46.4 & 2.12 & 0.62 \\
\hline Urinary $\mathrm{N} / \mathrm{N}$ intake & $30.7^{\mathrm{a}}$ & $26.6^{\mathrm{b}}$ & $25.0^{\mathrm{b}}$ & 0.68 & 0.05 \\
\hline Retained N/digested N & $38.7^{\mathrm{b}}$ & $48.7^{\mathrm{a}}$ & $53.3^{\mathrm{a}}$ & 1.39 & 0.03 \\
\hline
\end{tabular}

A: complete feed block without microbe; B: complete feed block containing $1 \% P$. aeruginosa and $1 \% A$. baumannii; C: complete feed block containing $2 \% P$. aeruginosa and $2 \%$ A. baumannii

${ }_{a, b}$ Within a row means were a common superscript did not differ with probability $P<0.05$

\section{Conclusion}

The addition of cellulolytic bacteria $P$. aeruginosa and $A$. baumannii to CFB reduced NDF and ADF contents. Block $\mathrm{C}$ was effective in modifying ruminal fermentation patterns by increasing concentrations of $\mathrm{NH}_{3}-\mathrm{N}$, acetate and total VFA. Digestibility of OM and NDF in blocks $\mathrm{B}$ and $\mathrm{C}$ was higher than that of control. The utilization of nitrogen expressed as ration of urinary $N$ to $N$ intake and retained $N$ to digested $N$ increased in goats fed on blocks B and C.

\section{Acknowledgements}

The work was supported by Indonesian Ministry of Research and Technology (No. 198/SP2H/LT/AMD/LT/DRPM/2020).

\section{Authors' Contributions}


BS developed the concepts, designed the experiments, and drafted the manuscript. MNL, TWW and BTH conducted the experiments, collected samples and did statistical analysis. All of them approved the final version of the article.

\section{Conflict of Interest Declaration}

The authors declared that they had no competing interest.

\section{References}

Abdulrazak, S.A., Muinga, R.W., Thorpe, W. \& Ørskov, E.R., 1997. Supplementation with Gliricidia sepium and Leucaena leucocephala on voluntary food intake, digestibility, rumen fermentation and live weight of crossbreed steers offered Zea mays stover. Livest. Prod. Sci. 49, 53-62. DOI: $10.1016 / \mathrm{S} 0301-6226(97) 00018-3$

AOAC (Association of Official Analytical Chemists) 2012. Official methods of analysis. 19th ed. Association of Official Analytical Chemists, Washington DC, USA.

Aschenbach, J.R., Penner, G.B., Stumpff, F. \& Gabel, G., 2011. Ruminant nutrition symposium: Role of fermentation acid absorption in the regulation of ruminal pH. J. Anim. Sci. 89, 1092-1107. DOI: 10.2527/jas.2010-3301

Bach, A., Calsamiglia, S. \& Stern, M.G. 2005. Nitrogen metabolism in the rumen. J. Dairy Sci. 88, E9-E21. DOI: 10.3168/JDS.S0022-0302(05)73133-7

Bussink, D.W. \& Oenema, O., 1998. Ammonia volatilization from dairy farming systems in temperate areas: A review. Nutr. Cycl. Agroecosyst. 51, 19-33. DOI: 1009747109538

Chang, D.H., Rhee, M.S., Jeong, H., Kim, S. \& Kim, B.C., 2015. Draft genome sequence of Acinetobacter sp. HR7, isolated from Hanwoo, Korean native cattle. Genome Announc. 3, 1-2. DOI: 10.1128/genomeA.01358-14

Dijkstra, J., 1994. Production and absorption of volatile fatty acids in the rumen. Livest. Prod. Sci. 39, 61-69. DOI: 10.1016/0301-6226(94)90154-6

Fondevila, M. \& Dehority, B.A., 1996. Interactions between Fibrobacter succinogenes, Prevotella ruminicola, and Ruminococcus flavefaciens in the digestion of cellulose from forages. J. Anim. Sci. 74, 678-684. DOI: $10.2527 / 1996.743678 X$

Karangiya, V.K., Savsani, H.H. \& Ribadiya, N.K., 2016. Use of densified complete feed blocks as ruminant feed for sustainable livestock production: A review. Agric. Rev. 37, 141-147. DOI: 10.18805/AR.V37I2.10739

Kearl, L.C., 1982. Nutrient requirements of ruminants in developing countries. International Feedstuff Institute, Utah State University, Logan, UT, USA.

Krause, K.M. \& Oetzel, G.R., 2006. Understanding and preventing subacute ruminal acidosis in dairy herds: A review. Anim. Feed Sci. Technol. 126, 215-236. DOI: 10.1016/J.ANIFEEDSCI.2005.08.004

McDonald, P., Edwards, R.A., Greenhalgh, J.F.D., Morgan, C.A., Sinclair, L.A. \& Wilkinson R.G., 2010. Animal nutrition. 7th ed. Pearson, London.

Minson, D.J. \& Milford, R., 1966. The energy values and nutritive value indices of Digitaria decumbens, Sorghum almum and Phaseolus atropurpureus. Aust. J. Agric. Res. 17, 411-423. DOI: 10.1071/AR9660411

Oyeleke, S.B. \& Okusanmi, T.A., 2008. Isolation and characterization of cellulose hydrolysing microorganism from the rumen of ruminants. Afr. J. Biotechnol. 7, 1503-1504. http://www.academicjournals.org/AJB

Prasad, C.S., Gowda, N.K.S. \& Rammana, J.V., 2001. Feeding strategies to enhance animal productivity. In: Proceedings of the Xth Animal Nutrition Conference, NDRI, Karnal, India. Pp. 23-45.

Ridwan, R., Bungsu, A.W., Astuti, W.D., Rohmatussolihat, Sari, N.F., Fidriyanto, R., Jayanegara, A., Wijayanti, I. \& Widyastuti, Y., 2018. The use of lactic acid bacteria as ruminant probiotic candidates based on in vitro rumen fermentation characteristics. Bull. Anim. Sci. 42, 31-36. DOI: 10.21059/BULETINPETERNAK.V42I1.23317

Russell, J.B. \& Wilson, D.B., 1996. Why are ruminal cellulolytic bacteria unable to digest cellulose at a low pH? J. Dairy Sci. 79, 1503-1509. DOI: 10.3168/JDS.S0022-0302(96)76510-4

Santoso, B. \& Hariadi, B.T., 2009. Evaluation of nutritive value and in vitro methane production of feedstuffs from agricultural and food industry by-products. J. Indonesian Trop. Anim. Agric. 34, 189-195. DOI: 10.14710/JITAA.34.3.189-195

Santoso, B., Kilmaskossu, A \& Sambodo, P., 2007. Effects of saponin from Biophytum petersianum Klotzsch on ruminal fermentation, microbial protein synthesis and nitrogen utilization in goats. Anim. Feed Sci. Technol. 137, 58-68. DOI: 10.1016/J.ANIFEEDSCI.2006.10.005

Santoso, B., Widayati, T.W. \& Hariadi, B.Tj., 2017. Nutritive value, in vitro fermentation characteristics and nutrient digestibility of agro-industrial byproducts-based complete feed block enriched with mixed microbes. Pak. J. Nutr. 16, 470-476. DOI: 10.3923/PJN.2017.470.476

Santoso, B., Lekitoo, M.N., Hariadi, B.Tj., Widayati, T.W. \& Abubakar. H., 2016. In vitro nutrients digestibility and fermentation characteristics of king grass combined with concentrate-containing mixed microbes. Pak. J. Nutr. 15, 784-788. DOI: 10.3923/PJN.2016.784.788

Santoso, B., Widayati, T.W., Lekitoo, M.N., Hariadi, B.Tj. \& Abubakar H., 2018. Evaluation of in vitro nutrient digestibility, fermentation characteristics and methane production of agro-industrial byproduct-based complete feed block treated with mixed microbes. Adv. Anim. Vet. Sci. 6, 258-264. DOI: 10.17582/journal.aavs/2018/6.6.258.264

Seo, J.K., Kim, S.W., Kim, M.H., Upadhaya, S.D., Kam, D.K. \& Ha, J.K., 2010. Direct-fed microbials for ruminant animals. Asian-Australas. J. Anim. Sci. 23, 1657-1667. DOI: 10.5713/AJAS.2010.R.08

Surabhi, K., Rangeshwaran, R., Frenita, M.L., Shylesha, A.N. \& Jagadeesh, P. 2018. Isolation and characterization of the culturable microbes associated with gut of adult dung beetle Onitis philemon (Fabricius). J. Pharmacogn. Phytochem. 27, 1609-1614. 
Uyeno, Y., Shigemori, S. \& Shimosato, T., 2015. Effect of probiotics/prebiotics on cattle health and productivity. Microbes Environ. 30, 126-132.

Van Soest, P.J., Robertson, J.B. \& Lewis, B.A., 1991. Methods for dietary fiber, neutral detergent fiber, and nonstarch polysaccharides in relation to animal nutrition. J. Dairy Sci. 74, 3583-3597. DOI: 10.3168/JDS.S00220302(91)78551-2

Van Soest, P.J., 1994. Nutritional ecology of the ruminant. 2nd ed. Comstock Publishing Associates, Ithaca, NY, USA. P. 476.

Wang, L., Zhang, G., Li, Y. \& Zhang, Y. 2020. Effects of high forage/concentrate diet on volatile fatty acid production and the microorganisms involved in VFA production in cow rumen. Animals 10, 223-235. DOI: 10.3390/ani10020223

Zain, M., Rahman, J. \& Kashrad, E., 2015. In vitro fermentation characteristics of palm oil byproducts which are supplemented with growth factor rumen microbes. Pak. J. Nutr. 14, 625-628. DOI: 10.3923/PJN.2015.625.628

Zhang, L., Chung, J., Jiang, Q., Sun, R., Zhang, J., Zhong, Y. \& Ren, N. 2017. Characteristics of rumen microorganisms involved in anaerobic degradation of cellulose at various $\mathrm{pH}$ values. RSC Adv. 7, 40303-40310. DOI: 10.1039/C7RA06588D

Zhu, W., Xu, W., Wei, C., Zhang, Z., Jiang, C. \& Chen, X. 2020. Effects of decreasing dietary crude protein level on growth performance, nutrient digestion, serum metabolites and nitrogen utilization in growing goat kids (Capra hircus). Animals 10, 151-161. DOI: 10.3390/ani10010151 